Маја Крстић

Универзитет у Новом Саду

Филозофски факултет

Одсек за славистику

maja.krstic@ff.uns.ac.rs
УДК 811.161.1'367.625:811.163.41'367.625

https://doi.org/10.18485/slavistika.2020.24.2.10

оригинални научни рад примљено 29.02.2020.

прихваћено за штампу 18.09.2020.

\title{
ГЛАГОЛ СЛУЖИТЬ И ЮЕГОВИ ЕКВИВАЛЕНТИ У СРПСКОМ ЈЕЗИКУ
}

Предмет датог рада је употреба глагола служить у руском језику и његови еквиваленти у српском. Пажња је у највећој мери усмерена на употребу датог глагола у саставу једног типа синтаксичких конструкција које гради. У таквој се употреби дати глагол десемантизује и поприма улогу глаголске копуле. Његова десементизација у оваквој употреби није потпуна, будући да он задржава део свог примарног значења, што га дистанцира од „праве“ копуле глагола быть и сврстава у групу семикопулативних глагола у руском језику. Полисемичност овог глагола усмерила је анализу и на друга значења и употребне могућности датог глагола, представљени су и системски еквиваленти у српском језику.

Кључне речи: глагол, служить, копула, десемантизација, руски језик, српски језик.

The paper addresses the use of the Russian verb служить (to serve) and its equivalents in the Serbian language. The main focus of attention is the use of a given verb in th composition of a type of syntactic constructions it constructs. In such use the given verb is desemantized and assumes the role of the verb copula. Its desemantization in such usage is not complete, since it retains some of its primary meaning, which separates it from the "real" copula - the verb to be (быть) - and classifies it as a semicopulative verb in the Russian language. The polysemy of this verb directed the analysis to other meanings and usable possibilities of the given verb, and systemic equivalents in the Serbian language were presented.

Keywords: verb to serve, copula, desemantization, Russian language, Serbian language.

\section{УВОДНЕ НАПОМЕНЕ.}

Дато истраживање је засновано на примерима са употребом глагола служить, ексцерпираних у националном корпусу руског језика (www.ruscorpora. ru) и у корпусу новинских текстова (http://lexicol.philol.msu.ru/cgi-bin/koi/corpus. corpus.query), доступним на интернету. Поред поменутих извора, као полазна тачка за анализу послужили су нам различити речници руског језика, који су наведени на крају рада.

Анализу датог глагола започећемо прегледом лексичко-семантичких особина глагола служить и описом појединачних значења која наводе лексикографски извори, што нам сведочи о његовој полисемичности. Централни део анализе биће посвећен употреби датог глагола у функцији семикопулативног глагола, јер у саставу синтаксичке конструкције коју гради у тој улози има веома фреквентну употребу у руском језику.

Глагол служить је често био предмет истраживања бројних руских (и страних) лингвиста и то управо са аспекта припадности групи семикопулативних глагола у руском језику (Авилова 1976; Акимова 1969; Арутюнова 1980; Валгина 1978; 
Всеволодова, Шувалова 1989; Глазман 1962, 1963; Голицына 1983; Крстић 2006, 2014, 2018; Попова 2011; Степанов 1980; Чернов 1976 и др.). Поред глагола служить, ову групу сачињавају и глаголи: являться, состоять, представлять (собой) и др., посебан тип копулативних (спонских) глагола у руском језику, који поред „праве“ копуле - глагола быть имају способност да творе један тип синтаксичких конструкција, о којима ће нешто касније бити речи. Глагол служсить засебно (изван ове групе) је био предмет истраживања у неколико наврата (Руднев 2014; Цзин 2019). Д. Руднев у свом раду пише о историји формирања глаголске копуле служить у руском језику, а Ли Цзин анализира глагол служить са аспекта теорије прототипа и наводи еквиваленте у кинеском језику. Новина нашег истраживања засниваће се на представљању системских еквивалената у српском језику.

\section{ЕТИМОЛОГИЈА.}

Етимологија овог глагола се везује за именицу слуга (старорус. слуга, старо-

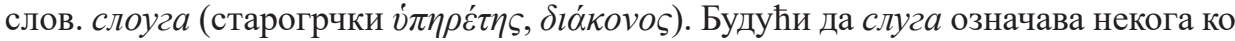
служи, помаже, налази се у потчињеном положају у односу на онога коме служи, отуд се и примарно значење овог глагола везује управо за такву функцију: служить / срп. служити (некоме):

Я думал, истинно служу государю и отечеству, а на поверку выходит, что я служу Барклаю. (www.ruscorpora.ru)

Именици слуга, од које је изведен глагол служсить, сродне су именице изведене из истог корена: служитель, служение, служба, служака, служанка, као и глаголи: служсться, прислужить и прослужить. Сви наведени облици везују се за значење 'служити некоме или нечему.'

\section{ЛЕКСИЧКО-СЕМАНТИЧКЕ ОСОБИНЕ ГЛАГОЛА СЛУЖИТЬ.}

Глагол служить је непрелазни глагол несвршеног вида, који има изражену полисемију. Видски пар му је глагол послужсть, али није адекватан сваком од наведених значења (в. даље - 4. и 5. значење).

Увид у лексикографске податке омогућио нам је да уочимо изразиту полисемичност глагола служить, који се, поред свог примарног и најфреквентнијег значења - 'служити' (имати функцију), веома често користи у другим, мање или више блиским значењима. Најтипичнији представник дате лексичко-семантичке категорије, коме припада централно место, је наведени глагол употребљен у значењу 'служити', 'имати функцију', док и све друге лексичко-семнтичке варијанте значења овог глагола такође сачињавају дату категорију. Наведена значења могу бити у међусобној директној или индиректној вези, а у зависности од контекста свако од поменутих значења може преузети доминантну улогу.

Полисемија се јавља када реч добија додатно значење, које се временом удаљава од првобитног смисла. Лексикографски извори приказују следећа значења глагола служить (в.: Речници):

1.1 'Работать по найму, исполнять обязанности служащего.' - Изволите служить? - Теперь нет; дела мои требовали, чтоб я покинул службу на некоторое время. (Герцен, Записки одного молодого человека). 
1.2 'Быть слугой, прислугой.’ У тети каждую неделю менялись кухарки и горничные. Из своих деревенских никто не шел служить и приходилось нанимать дальних. (Чехов, В родном углу).

1.3 кому. 'Исполнять какие-л. обязанности по отношению к кому-л., выполнять чью-л. волю, находясь в чьей-л. власти, подчиняясь кому-л.' - Скрыввавшиеся в лесах остатки побежденных вернулись в город и стали служить победителям. (А. Н. Толстой, Аэлита) \| Оказывать какие-л. услуги кому-л. [Купавина:] Мне нужно посоветоваться, а не с кем было. Вы мне не откажете? [Глафира:] Рада служить вам всем, чем могу. (А. Островский, Волки и овцы). ${ }^{1}$

Употребљен у наведена три (међусобно веома блиска) значења, глагол служить означава 'радити по нечијој вољи', 'служити некоме', ‘ бити у потчињеном положају у односу на некога’, ‘ бити слуга'. Речи са заједничким кореном (-слуг): слуга, служанка, служить поседују исто значење: 'пружати услугу’, 'служити некоме'.

У српском језику еквивалентан је глагол служити, а такође постоји група речи са истим кореном (слуга, служавка, послуга), која одговара наведеном значењу у руском језику.

2. 'Исполнять воинские обязанности, быть на военной службе.' Господин Перекатов служил некогда в кавалерии. (Тургенев, Бретер).

У оваквој употреби глагол служить има значење 'служити војску’, ‘служити отаџбини', што је од 1874. године у Руској империји постала обавеза мушке популације.

Еквивалент у српском језику је исти: служити војску, служити отацбини, што је такође у минулим временима у Србији представљало обавезу лицима мушког пола.

3. кому-чему. 'Работать, трудиться во имя чего-л., на благо кого-, чего-л.' $Я$ лиру посвятил народу своему. Быть может, я умру неведомый ему, Но я ему служил - и сердием я спокоен (Н. Некрасов, Элегия).

Употребљен на овај начин, глагол служить носи смисао 'радити, трудити се, залагати се за нечије/некакво добро'. У руском језику постоји фраза служить детям или мужу, која има смисао ‘бринути се о деци или мужу’, што се у традиционалној руској породици сматра обавезом жене, која даје све од себе за добробит своје породице (служи својој породици).

Српски еквивалент у овом случају је глагол залагати се, бринути се, посветити се некоме/нечему. У српском језику глагол служити може бити употребљен на овај начин у одређеном контексту (служити мужу), али у таквој употреби поприма смисао 'бити у потчињеном положају у односу на мужа', стога би за савремени српски језик био адекватнији глагол посветити се (Она се посветила своме мужу, деци, породици). У српском језику се 'посвећујемо’ и неким вишим циљевима, идеалима, постизању одређених резултата у корист свога народа, државе и сл.

\footnotetext{
${ }^{1}$ Наведена три значења (која смо подвели у подгрупу једног значења) речници наводе засебно.
} 
4. (сов. послужить). 'Выполнять свое назначение' (о частях, органах тела, вещах, орудиях и т. п.). Я утомился от усиленной работы, мозг отказывался служить. (Серафимович, Прогулка). \| чем, для чего. Выполнять. какое-л. назначение, использоваться для чего-л. Красный широкий сафьянный диван очевидно служил Рогожину постелью. (Достоевский, Идиот).

У наведеном значењу субјекат није живо биће, већ неку функцију 'служи' (испуњава) део тела човека (мозак, срце) или неки комад намештаја, одећа, обућа, оружје или оруђе. У примеру Атомные подводныле лодки, аэробусы, гигантские плотины, ядерные реакторы не могут служить вечно - уочава се веза са значењем ‘служить в армии' (као што војску служе војници), тј. војсци служе како жива бића, тако и предмети (оружје, оруђе и сл.), а у примеру Красный широкий сафьянный диван очевидно служил Рогожину постелью - можемо говорити о ширењу употребе горенаведеног значења у сферу свакодневног говора (Цзин 2019).

У српском језику се у овом значењу такође користи глагол служити: кауч служи за спавање, касарне служе војсии, ово посуђе више ни за шта не служи. Када се глагол служить везује за неки део човековог тела (голова отказывается служить) обично је реч о алегорији, тј. указује се на то да “глава (мозак) не ради како треба', док би српски еквивалент у овом случају био 'издала (га) је памет' (памет га више не служи).

5. (сов. послужить) чем. В сочетании с некоторыми существительными означает: 'быть, являться чем-л.' Служить примером. Служить доказательством. Отеи повел плечами и поправил шляпу на голове - что у него всегда служило признаком нетерпения. (Тургенев, Первая любовь).

Структуре овог типа (служить примером, служить доказательством) карактеристичне су пре свега за научни стил језика, у којима је субјекат најчешће апстрактна именица са значењем 'вршити неку функцију'.

Српски еквивалент и у овом значењу био би глагол служити, који се такође најчешће везује уз апстрактне именице: служити као пример (некоме), служити као доказ (нечему) и сл.

6. перех. и без доп. 'Отправлять церковную службу’. Служил новый поп, отец Александр. (Эртель, Гарденины).

Руски фразеологизми молебен служить, служить обедню, служить литургию користе се у значењу 'совершать церковные обряды' (вршити црквене обреде). Дато значење тесно је повезано са значењем 'служить в армии', jep ‘служити војску’ представља обавезу пред државом, а 'служити у цркви’ - обавезу пред Богом. У Библији се такође говори о служењу Богу, што у себи носи одређену конотацију потчињености и односу слуга-господар, верници су потчињени Богу, као и војници своме официру.

У српском језику се у овом значењу користи исти глагол: служити литургију, служсти мису, али и вршити (вршити црквене обреде, вриити службу).

7. 'Стоять на задних лапах, вытянув или подняв передние' (о некоторых животных). - Прыгай, Перезвон, служи! Служи! - завопил Коля, вскочив с места, и собака, став на задние лапь, вытянулась прямо пред постелькой Илюши. (Достоевский, Братья Карамазовы). (СРЯ 1999) 
На први поглед нам се може учинити да семантика у овом случају нема везе са семантиком у претходно наведеним примерима. Међутим, ово значење глагола служить може врло лако да се повеже са горенаведеним значењима. Наиме, пси - на које се односи дата употреба су такође 'служили војсци', помажући људима својим истанчаним њухом у откривању мина и сл. То су 'службени пси' и попут војника, служе у војсци. Управо одатле је потекла најједноставнија команда упућена псима: Служси!, која се данас користи приликом дресирања паса како би се научили да стоје на задњим шапама (Цзин 2019).

У српском језику се глагол служити не користи у оваквом значењу. Приликом дресуре паса најчешће можемо чути команде: седи, лези, устани, дођи, донеси и др., а у овом случају (стојати на задњим шапама) српски еквивалент би био глагол шенити (Шени!).

Анализа лексичко-семантичких особина глагола служить омогућила нам је да уочимо да је само у два значења остварена опозиција служить - послужить (4. и 5. значење), односно да је употреба свршеног вида могућа једино када се глагол служить користи уз именице које означавају неживо (уз апстрактне именице или именице које означавају предмете, оруђе, оружје и сл.).

Када посматрамо еквиваленте у српском језику, уочавамо да је у већини значења еквиавлентан исти глагол: служити (осим у значењима 3 и 7). У 3. значењу ('работать, трудиться во имя чего-л., на благо кого-, чего-л.') у српском језику користе се глаголи: залагати се, бринути се, посветити се некоме/нечемy, док је у 7. значењу, у којем се употреба овог глагола односи на псе ( на задних лапах, вытянув или подняв передние') за српски језик карактеристична употреба глагола шенити.

\section{ГЛАГОЛ СЛУЖИТЬ У КОПУЛАТИВНОЈ ФУНКЦИЈИ.}

Једино се пето (горенаведено) значење датог глагола (служить (кем-, чем-л.)) у извесној мери разликује по својој употреби од осталих наведених значења: ‘бити, представљати'. Само у оваквој употреби дати глагол не представља самостални пунозначни глагол, већ се може реализовати једино у саставу сложеног именског предиката. У таквим конструкцијама он своје значење везује за значење именског дела дате конструкције и заједно чине једну семантичку целину. Значење такве конструкције зависи првенствено од њеног именског дела, а глагол служить има спонску улогу (копулативну). У спојевима овог типа његов задатак је да повеже два именска дела: именски део у номинативу (предњи део конструкције) са именским делом у инструменталу (задњи део конструкције). Спонски глаголи обично заузимају средишње место у таквим конструкцијама и имају везивну улогу. Задњи део конструкције (именски део у инструменталу) најчешће чини именица или (ређе) придев:

Люди верили, что имя человека служит источником его счастья и сил и каждый раз, когда его произносят, оно как будто немного снашивается. (www.ruscorpora.ru)

Важно је истаћи да глаголи овог типа у описаним конструкцијама ипак не бивају потпуно десемантизовани. Десемантизација најчешће доводи до изједначавања у значењу са глаголом бити, представљати (быть (кем-, чем-л.), яв- 
ляться (кем-, чем-л.), представлять собой), које глагол служсить поприма у саставу датих конструкција. За разлику од копулативног глагола быть (кем-, чем-л.), који се једини сматра „правим“ спонским глаголом, глаголи служить (кем-, чем-л.), являться (кем-, чем-л.), представлять собой, состоять (в чем), заключаться (в чем) и сл., називају се семикопулативним (полуспонским) глаголима, управо због тога што у овакве конструкције уносе делимично очувано сопствено примарно значење (Всеволодова, 2000: 55):

служсить - указује на функцију субјекта (Нефть служит сырьем для фармачевтики.)

являться - има значење оцене (Нефть является (не: служит!) прекрасным сырьем для фармачевтики.)

представлять собой - користи се када се субјекат карактерише по форми, структури и сл. (Нефть представляет собой густую темную маслянистую жидкость.).

Употреба глаголских копула је карактеристична за биноминативне реченице, у којима глаголи овог типа имају ослабљено лексичко значење и првенствено врше граматичку улогу, а значење се, као што смо истакли, изражава именским делом дате конструкције (Крстић (Радовановић) 2006, 2014, 2018).

Десемантизација глагола служить (кем-, чем-л.) испољава се на неколико нивоа: код граматичких категорија вида, времена и лица, у сфери употребе, (не)могућности успостављања синонимских односа итд. Када се посматра категорија вида овог глагола, могу се уочити следеће чињенице: за разлику од других семикопулативних глагола овог типа (являться (кем-, чем-л.), представлять собой и др.), код којих у оваквој употреби форми несвршеног вида не одговара његов парњак свршеног вида (являться (кем-, чем-л.) $\neq$ явиться; представлять собой $\neq$ представить), код глагола служить (кем-, чем-л.) ситуација је супротна. Наиме, управо у оваквој употреби му је адекватан видски парњак - глагол послужить, док у осталим употребама овог глагола - није. Десемантизација се огледа и у ограниченој употреби категорије лица и времена копулативног глагола служить (кем-, чем-л.), јер се у оваквој функцији он претежно користи у садашњем времену, у 3. лицу једнине или множине. Са друге стране, пунозначни глагол служить има регуларну употребу у свим лицима и релативно подједнаку употребу у свим глаголским временима. Десемантизацију овог глагола показује и ограничена сфера његове употребе. Глагол служсть (кем-, чем-л.) је у највећој мери типичан за научни стил језика, јер се веома често користи у различитим дефиницијама. Заступљен је и у публицистици, пословном стилу језика, док говорном стилу (у оваквој употреби) није својствен. За разлику од њега, глагол служить не познаје стилска ограничења. На десемантизацију овог глагола указује и (не)могућност успостављања синонимских односа. Док глагол служить има читав низ различитих синонима: $p a-$ ботать, состоять, подчиняться, поклоняться, предназначаться, помогать, угождать, ухаживать, содействовать, прислуживать, услуживать, повиноваться, священнодействовать, действоать, фурычить и др., глаголу служить (кем-, чем-л.) синонимични су искључиво семикопулативни глаголи са значењем 'бити' (быть (кем-, чем-л.), являться (кем-, чем-л.), являть собой / из себя (кого- 
, что-л.), изображатя собой / из себя (кого-, что-л.), выступпать в качестве (кого-, чего-л.), представлять собой). Најзад, треба истаћи да десемантизација не своди глагол служить (кем-, чем-л.) искључиво на показатеља граматичких категорија сложеног предиката, већ дати глагол ипак задржава одређени семантички потенцијал, који испољава у оквиру конструкција чији је саставни део. Значење које изражавају овакве конструкције не припада глаголу, већ читавој конструкцији, а оно зависи првенствено од њеног именског дела.

\section{АСОЦИЈАЦИЈЕ.}

Најчешће асоцијације које се односе на овај глагол су пре свега везане за војну терминологију: армия, солдат, военный, флот, войско, разведка, штаб, кавалерия, спецназ, командование, охрана, гвардия, полк, граница, отряд, авиациия, пехота, война, легион, артиллерия, корпус, контрразведка, гарнизон; затим за државну службу: полициия, милиция, министерство, отдел, орган, управление, посольство, Россия, контора, начальство, город, должность; за породицу и дом: двор, дом, отец; за црквену службу: храм, цүерковь, священник (https:// kartaslov.ru/значение-слова/служить).

Највећи број асоцијација односи се на војну терминологију. Ови подаци нам указују на то да се употреба овог глагола, који се примарно везује за службу у војсци, службу домовини, раширила и на друге сфере живота, па тако и оружје може да служи војнику (војсци), као и пас. Поред војне службе, човеку служе и предмети који га окружују и који су му неопходни за живот, служи му и памет, срце, руке.

\section{ИМЕНИЦЕ КОЈЕ СЕ КОРИСТЕ СА ГЛАГОЛОМ СЛУЖИТЬ.}

Именице, које се најчешће користе са глаголом служить су бројне: отец, год, замок, сын, камень, человек, брат, предок, дерево, флот, помещуение, стена, день, митрополит, муж, священник, парень, дед, место, имя, здание, торговля, офицер, корабль, время, папа, мать, помост, река, ребёнок, храм, оружие, родитель, обстоятельство, одежда, женщина, солдат, слово, башня, меч, рука, орган, дядя, повод, пример, друг, жизнь, остров, епископ, окно, семья, животное, зал, воин, родственник, часть, лейтенант, ичифра и др. (https:// kartaslov.ru/значение-слова/служить).

Анализа именица које се најчешће везују са глаголом служить показала нам је да се уз дати глагол највише користе именице из сфере опште лексике, односно жива бића и предмети из свакодневног живота човека. То нам указује на чињеницу да је дати глагол широко распрострањен у свакодневној употреби. Поред опште лексике, фреквентан је у научном стилу језика (обстоятельство, пример), широку употребу има у области војне терминологије (солдат, воин, офицер), као и у домену црквене лексике (митрополит, епископ, священник).

\section{СПОЈЕВИ РЕЧИ И ФРАЗЕОЛОГИЗМИ СА ГЛАГОЛОМ СЛУЖИТЬ.}

Анализа прикупљеног материјала омогућила нам је да уочимо најтипичније спојеве речи који се користе са глаголом служить: служить причиной, осно- 
вой, примером, поводом, источником, доказательством, основанием, сигналом, средством, началом, защитой, образиом, полчком, местом, опорой, потверждением, предметом, признаком, верой и правдой, напоминанием, иллюстраиией, ориентиром, оправданием, символом, материалом, гарантией, знаком, орудием, утешением, оружием, проводником, моделью, свидетельством, катализатором, залогом, препятсвтием, базой, показателем, инструментом, фактором, предлогом, выражением, объяснением, иентром, ответом, ключом, аргументом итд.; као и фразеологизме: служить Бахусу и служить мамоне. Фразеологизам служить Бахусу је шаљивог карактера и значи `пити вино, пијанчити, приносити жртву богу вина' (поклоняться Бахусу / служить Бахусу). Бахус је у римској митологији представљао бога вина и весеља. Фразеологизам служсить мамоне је религиозног карактера и односи се на Мамону - сиријско божанство, заштитницу земаљских блага, односно богатсва. Дати фразеологизам има значење да су духовно и материјално неспојиви ('Не можете служить Богу и мамоне').

Анализа асоцијација везаних за глагол служсть показала је да се највећи број асоцијација односи на лексику из области војне терминологије, док смо увидом у списак именица које се најчешће користе са овим глаголом уочили да су у више од $60 \%$ примера употребљене именице које припадају сфери опште лексике. Најчешћи спојеви речи нам дају сасвим другачију слику - код њих се уз глагол служить у готово 90\% примера користе апстрактне именице, својствене, пре свега, научном стилу језика.

Након спроведеног истраживања на примерима из Националног корпуса руског језика и Корпуса новинских текстова, дошли смо до закључка да је дати глагол најфреквентнији у сфери опште лескике (42\%), затим војне терминологије (29\%), у сфери црквене терминологије (18\%) и осталим (горенаведеним) значењима (11\%).

\section{ЗАКЉУЧНЕ НАПОМЕНЕ.}

Извршена анализа омогућила нам је да дођемо до неколико значајних запажања: глагол служсть има изражену полисемију, а у зависности од значења и широк спектар употребних могућности у различитим сферама. Најчешћу употребу дати глагол има у значењу 'вршити одређену функцију'; 'служити у војсци'; 'радити, бити у служби / служити (интересима) државе, друштва'; 'служити (некоме), бити у подређеном положају'; док се незнатно ређе односи на црквену службу или заповедање псу да стане на задње ноге. Поред наведених значења у којима се глагол служить понаша као самостални (пунозначни) глагол са регуларном употребом, издвојили смо једно значење које одступа од претходно поменутих: 'бити, представљати.' Овакво значење дати глагол има када се користи у саставу сложеног именског предиката, где врши функцију спонског глагола. У оквиру таквих конструкција он подлеже десемантизацији и поприма значење ‘бити, представљати' и првенствено врши граматичку улогу. Значење оваквих конструкција првенствено зависи од именског дела, али семикопулативни глаголи (у овом случају глагол служить) чувају део свог примарног значења (за разлику од копулативног глагола быть) и уносе 
га у конструкцију чији су саставни део. Анализом употребе глагола служить у осталим значењима, уочили смо да је најфреквентнији у сфери опште лексике, у области војне терминологије, као и у другим наведеним значењима.

\section{Цитирана литература}

Авилова, Наталья С. Вид глагола и семантика глагольного слова. Москва, 1976. [Avilova, Natal'â S. Vid glagola i semantika glagol'nogo slova. Moskva, 1976]

Акимова, Галина. Н. Полузнаменательные и знаменательные связки в языке Ломоносова. Очерки по истории русского языка и литературы 18 в., вып.2-3. Казань, 1969.

[Akimova, Galina. N. Poluznamenatel'nye i znamenatel'nye svâzki v âzyke Lomonosova. Ocherki po istorii russkogo âzyka i literatury 18 v., vyp.2-3. Kazan', 1969]

Арутюнова, Нина Д. Сокровенная связка /к проблеме предикативного отношения/. Москва: Известия Академии наук СССР, Серия литературы и языка, Т. 39, 4, 1980.

[Arutûnova, Nina D. Sokrovennaâ svâzka /k probleme predikativnogo otnosheniâ/. Moskva: Izvestiâ Akademii nauk SSSR, Seriâ literatury i âzyka, T. 39, 4, 1980]

Бондарко, Александр В. Грамматическая категория и контекст. Ленинград: АНСССР, "Наука", 1971.

[Bondarko, Aleksandr V. Grammaticheskaâ kategoriâ i kontekst. Leningrad: ANSSSR, "Nauka", 1971]

Валгина, Нина С. Синатаксис современного русского языка. Москва, 1978.

[Valgina, Nina S. Sinataksis sovremennogo russkogo âzyka. Moskva, 1978]

Всеволодова, Майя В. Теория функционально-коммуникативного синтаксиса. Москва: МГУ, 2000.

[Vsevolodova, Mă̌â V. Teoriâ funktșional'no-kommunikativnogo sintaksisa. Moskva: MGU, 2000]

Всеволодова, Майя В., Светлана А. Шувалова. Вопросы коммуникативно-функционального описания синтаксического строя русского языка. Москва: МГУ, 1989.

[Vsevolodova, Maŭâ V., Svetlana A. SHuvalova. Voprosy kommunikativnofunktşional'nogo opisaniâ sintaksicheskogo stroâ russkogo âzyka. Moskva: MGU, 1989]

Гак, Владимир Г. Десемантизация языкового знака в аналитических структуpax синтаксиса, Аналитические конструкции в языках различных типов. МоскваЛенинград: АНСССР, 1965.

[Gak, Vladimir G. Desemantizatşiâ âzykovogo znaka v analiticheskikh strukturakh sintaksisa, Analiticheskie konstruktşii v âzykakh razlichnykh tipov. Moskva-Leningrad: ANSSSR, 1965]

Глазман, Мира. А. «Об использовании глаголов в качестве связок в составном сказуемом». [В:] Сборник рефератов научных работ, вып.2. Алма-Ата, 1962: 35-36.

[Glazman, Mira. A. «Ob ispol'zovanii glagolov v kachestve svâzok v sostavnom skazuemom». [V:] Sbornik referatov nauchnykh rabot, vyp.2. Alma-Ata, 1962: 35-36]

Глазман, Мира. А. «К вопросу о взаимодействии лексического и грамматического в глагольных связках составного сказуемого». [В:] Филологический сборник, вып.1. Алма-Ата, 1963: 74-78.

[Glazman, Mira. A. «K voprosu o vzaimodeřstvii leksicheskogo i grammaticheskogo v glagol'nykh svâzkakh sostavnogo skazuemogo». [V:] Filologicheskil̆ sbornik, vyp.1. 
Alma-Ata, 1963: 74-78]

Голицына, Татьяна Н. Служебные (связочные) глаголы русккого языка и их полнозначные соответствия. Афтореф. дис. ... канд. филол. наук. Воронежский гос. унт. Воронеж, 1983.

[Golitŝnna, Tat'âna N. Sluzhebnye (svâzochnye) glagoly ruskkogo âzyka i ikh polnoznachnye sootvetstviâ. Aftoref. dis. ... kand. filol. nauk. Voronezhskiĭ gos. un-t. Voronezh, 1983]

Крстић (Радовановић), Маја. «Конструкције са глаголом являться у руском језику». Годишњак Филозофског факултета у Новом Саду, књ. XXIII, 2006: 65-75.

[Krstić (Radovanović), Maja. «Konstrukcije sa glagolom âvlât'sâ u ruskom jeziku». Godišnjak Filozofskog fakulteta u Novom Sadu, knj. XXIII, 2006: 65-75]

Крстић, Маја. «О употреби копулативних глагола у руском и српском језику». Славистика, књ. XVIII, 2014: 268-274.

[Krstić, Maja. «O upotrebi kopulativnih glagola u ruskom i srpskom jeziku». Slavistika, knj. XVIII, 2014: 268-274]

Крстич, Майя. «Значение и употребление глагола состоять и его эквиваленты в сербском языке». Вестник Волгоградского государственного университета. Серия 2, Языкознание. - 2018. - Т. 17, № 4. -C. 188-196. - DOI: https://doi.org/10.15688/ jvolsu2.2018.4.18.

[Krstić, Maja. «Znachenie i upotreblenie glagola sostoât' i ego ėkvivalenty v serbskom âzyke». Vestnik Volgogradskogo gosudarstvennogo universiteta. Seriâ 2, Âzykoznanie. - 2018. - T. 17, № 4. -S. 188-196. - DOI: https://doi.org/10.15688/jvolsu2.2018.4.18]

Лекант, Павел А. Типы и формы сказуемого в современном русском языке. Москва, 1976.

[Lekant, Pavel A. Tipy i formy skazuemogo v sovremennom russkom âzyke. Moskva, 1976]

Пешковский, Александр М. Русский синтаксис в научном освещении. Москва, 2001.

[Peshkovskiǐ, Aleksandr M. Russkiı̌ sintaksis v nauchnom osveshchenii. Moskva, 2001]

Попова, Лариса. В. О месте связки в грамматической системе русского языка // Известия ПГПУ им. В. Г. Белинского. № 23, 2011: 215-218 (Научная библиотека КиберЛенинка: http:/cyberleninka.ru/article/n/o-meste-svyazki-v-grammaticheskoysisteme-russkogo-yazyka\#ixzz2b8bhQbRN)

[Popova, Larisa. V. O meste svâzki v grammaticheskoř sisteme russkogo âzyka // Izvestiâ PGPU im. V. G. Belinskogo. № 23, 2011: 215-218 (Nauchnaâ biblioteka KiberLeninka: http://cyberleninka.ru/article/n/o-meste-svyazki-v-grammaticheskoysisteme-russkogo-yazyka\#ixzz2b8bhQbRN)]

Руднев, Дмитрий В. «История формирования в русском языке глагольной связки служить». Вестник СПбГУ. Сер, 9. 2014. ВП. 1: 210-220.

[Rudnev, Dmitriı̌ V. «Istoriâ formirovaniâ v russkom âzyke glagol'noĭ svâzki sluzhit'». Vestnik SPbGU. Ser, 9. 2014. Vp. 1: 210-220]

Степанов, Юрий С. К универсальной классификации предикатов. Москва: Известия Академии наук СССР, Серия литературы и языка, Т. 39, 4, 1980.

[Stepanov, Ûrǐ̌ S. K universal'noǐ klassifikatșii predikatov. Moskva: Izvestiâ Akademii nauk SSSR, Seriâ literatury i âzyka, T. 39, 4, 1980]

Цзин, Ли. «Русский глагол „служить“ и его китайские эквиваленты». Языки народов зарубежных стран Европы, Азии, Африки. Филологический аспект, № 12 (56). Научно-издательский центр Открытое знание, 2019: 61-69. 
[TSzin, Li. «Russkiı̌ glagol „sluzhit'“ i ego kită̌skie èkvivalenty». Âzyki narodov zarubezhnykh stran Evropy, Azii, Afriki. Filologicheskiǐ aspekt, № 12 (56). Nauchnoizdatel'skiǐ tşentr Otkrytoe znanie, 2019: 61-69]

Чернов, Владимир И. «Полузнаменательные связочные глаголы в современном русском языке». Вопросы русского языкознания. Вып.1. Куйбышев, 1976: 71-88.

[CHernov, Vladimir. I. «Poluznamenatel'nye svâzochnye glagoly v sovremennom russkom âzyke». Voprosy russkogo âzykoznaniâ. Vyp.1. Kuǐbyshev, 1976: 71-88]

\section{Речницุи}

Абрамов, Николай А. Словарь русских синонимов и сходных по смыслу выражений. Москва, 1999.

[Abramov, Nikolaĭ A. Slovar' russkikh sinonimov i skhodnykh po smyslu vyrazheniı̌. Moskva, 1999]

Александрова, Зинаида Е. Словарь синонимов русского языка. Москва, 1969.

[Aleksandrova, Zinaida E. Slovar' sinonimov russkogo âzyka. Moskva, 1969]

Ефремова, Татьяна Ф. Новый словарь русского языка, Т. 2, Москва, 2000.

[Efremova, Tat'âna F. Novyǐ slovar' russkogo âzyka, T. 2, Moskva, 2000]

Лебедева, Марина Н. Словарь-справочник синтаксической сочетаемости глаголов. Москва, 2001.

[Lebedeva, Marina N. Slovar'-spravochnik sintaksicheskoř sochetaemosti glagolov. Moskva, 2001]

НОССРЯ: Новый объяснительный словарь синонимов русского языка, под рук. Ю. Д. Апресяна. Второй выпуск. Москва: РАН, 2000.

[NOSSRÂ: Novyǐ ob"âsnitel'ny̌̌ slovar' sinonimov russkogo âzyka, pod ruk. Û. D. Apresâna. Vtoroĭ vypusk. Moskva: RAN, 2000]

Ожегов, Сергей И., Шведова Наталия Ю. Толковый словарь русского языка. Москва: РАН, 1999.

[Ozhegov, Sergeř I., SHvedova Nataliâ Û. Tolkovyı̌ slovar' russkogo âzyka. Moskva: RAN, 1999]

Окунева, А. П. Русский глагол, Словарь-справочник. Москва, 2000.

[Okuneva, A. P. Russkiǐ glagol, Slovar'-spravochnik. Moskva, 2000]

PCJ: Речник српскога језика / Редиговао и уредио М. Николић. Нови Сад: Матица Српска, 2007.

[RSJ: Rečnik srpskoga jezika / Redigovao i uredio M. Nikolić. Novi Sad: Matica Srpska, 2007]

СРЯ: Словарь русского языка: В 4-х т. / РАН. Ин-т лингвистич. исследований; Под ред. А. П. Евгеньевой. - 4-е изд., стер. - М.: Рус. яз.; Полиграфресурсы, 1999; (электронная версия): Фундаментальная электронная библиотека.

[SRÂ: Slovar' russkogo âzyka: V 4-kh t. / RAN. In-t lingvistich. issledovaniǔ; Pod red. A. P. Evgen'evol. - 4-e izd., ster. - M.: Rus. âz.; Poligrafresursy, 1999; (èlektronnaâ versiâ): Fundamental'naâ èlektronnaâ biblioteka]

CC: Словарь синонимов. Ленинград: АНСССР, Институт русского языка, 1975.

[SS: Slovar' sinonimov. Leningrad: ANSSSR, Institut russkogo âzyka, 1975]

ССРЯ: Словарь синонимов русского языка. Т. 2. Ленинград: АНСССР, Институт русского языка, 1971. 
[SSRÂ: Slovar' sinonimov russkogo âzyka. T. 2. Leningrad: ANSSSR, Institut russkogo âzyka, 1971]

СФСРЯ: Словарь фразеологических синонимов русского языка, под ред. В. П. Жукова. Москва, 1987.

[SFSRÂ: Slovar' frazeologicheskikh sinonimov russkogo âzyka, pod red. V. P. ZHukova. Moskva, 1987]

ТСРЯ: Толковый словарь русского языка, под ред. Б. М. Волина и Д. Н. Ушакова, T. IV. Москва, 1940.

[TSRÂ: Tolkovyı̌ slovar' russkogo âzyka, pod red. B. M. Volina i D. N. Ushakova, T. IV. Moskva, 1940]

\section{Извори}

Запрос по корпусу газетных текстов: http://lexicol.philol.msu.ru/cgi-bin/koi/corpus. corpus.query

[Zapros po korpusu gazetnykh tekstov: http://lexicol.philol.msu.ru/cgi-bin/koi/corpus. corpus.query]

Национальный корпус русского языка: www.ruscorpora.ru

[Natsึional'nyĭ korpus russkogo âzyka: www.ruscorpora.ru]

Онлайн-карта слов и выражений русского языка: www.kartaslov.ru

[Onlaĭn-karta slov i vyrazheniı̌ russkogo âzyka: www.kartaslov.ru]

\section{Майя Крстич}

\section{ГЛАГОЛ СЛУЖИТЬ И ЕГО ЭКВИВАЛЕНТЫ В СЕРБСКОМ ЯЗЫКЕ}

\section{Резюме}

Глагол служить имеет несколько различных значений и, в зависимости от значения, широкий спектр возможностей его использования в разных сферах. В большинстве случаев данный глагол имеет значение 'служить кому-то, помогать (кому-то), быть в подчиненном положении'; 'работать, служить / служить (интересам) государству, обществу'; 'выполнять определенную функцию’ и 'служить в армии', а также может обозначать и церковное служение, и команду собаке выполнить стойку на задних лапах. В дополнение к вышеприведенным значениям, в которых глагол служить представляет собой полнозначный глагол с регулярным употреблением, мы выделили одно значение, которое отличается от всех вышеупомянутых: 'быть, представлять собой'. Такое значение данный глагол приобретает в конструкциях с составным именным сказуемым, в составе которого он выполняет роль связочного глагола. В данных конструкциях глагол служить подвергается десемантизации и выполняет грамматическую функцию, однако сохраняет часть своего основного значения (в отличие от глагола быть).

Ключевые слова: глагол, служить, связка, десемантизация, русский язык, сербский язык. 